\title{
Százötven éve született Illyés Géza, a magyar urológia első tanszékvezető professzora
}

\author{
Romics Imre dr.
}

Semmelweis Egyetem, Általános Orvostudományi Kar, Urológiai Klinika, Budapest

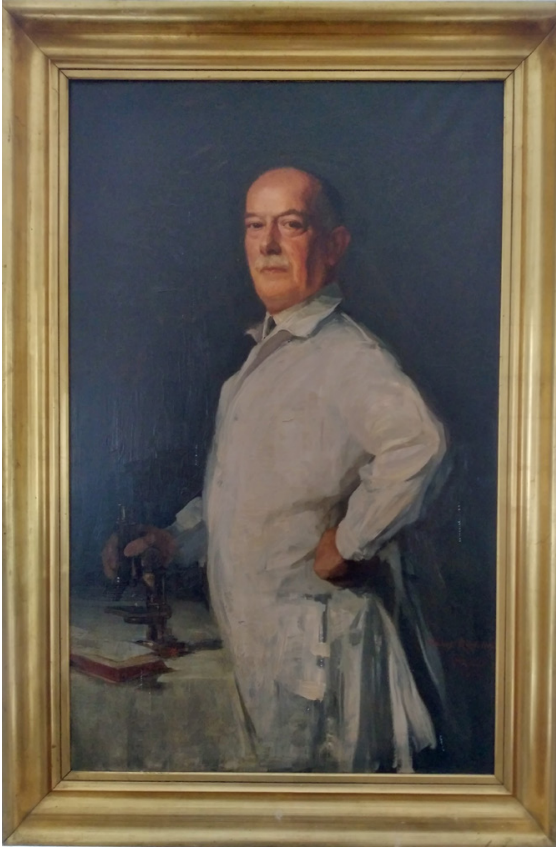

1. ábra

| Illyés Géza professzor (1870-1951)

Illyés Géza (1. ábra) 1870. május 24-én született Marosvásárhelyen (ma Târgu Mureș, Románia). Édesapja törvényszéki bíró, majd táblabíró lett. Elemi és középiskoláit Marosvásárhelyen végezte, 1888-ban érettségizett a református gimnáziumban. Nagyon vonzotta a katonai pálya - Vásárhelyen jelentős katonaság állomásozott, katonai alreáliskola is múködött. De az érettségi évében édesapját Budapestre helyezték, és Illyés a Pázmány Péter Tudományegyetem orvosi fakultására iratkozott be. Medikuséveiben Genersich Antal hatására a kórbonctan volt a kedvenc tantárgya, két évig demonstrátor is volt $[1,2]$.

1893 decemberében avatták orvosdoktorrá. Először Kétly Károly belgyógyászati klinikáján volt másfél évig, erről igazolást is kapott (2. ábra), majd 1895 szeptemberében a Dollinger Gyula vezette I. Sebészeti Klinikán folytatta tevékenységét. 1898-ban sebészeti szakképesí-

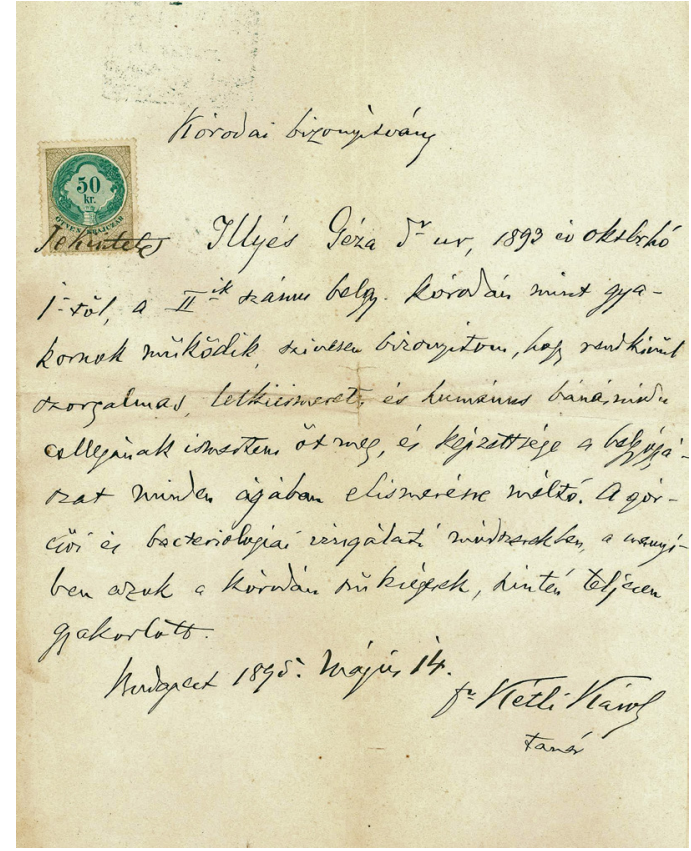

2. ábra

| Igazolás a Kétly Károly belgyógyászati klinikáján töltött időról

tést kapott. Ezt követően lett a klinika 2. tanársegédje. 1900 tavaszán már első tanársegéd - nagy rang volt ez akkor. Az ezt követő években fordult érdeklődése az urológiai betegségek felé.

Dollingeren (3. ábra) keresztül Illyés jó örököse volt a Balassa-iskolának, hiszen Balassa János is végzett urológiai mútéteket. Nagyot lendített az urológián a XIX. század második felében felfedezett cisztoszkóp (1879; Max Nitze, berlini orvos és Josef Leiter, bécsi múszerész). 1897-ben Joaquín Albarrán tökéletesítette az eszközt, megalkotva az ureterocisztoszkópot [3]. Ez a lényeges felfedezés az volt, hogy a cisztoszkóp végén levő kis fémnyelvet, mellyel az ureterkatétert a szájadékba lehetett irányítani, kívülről egy forgatható kerékkel lehetett mozgatni. Erről írt egy értekezést két részben Illyés 1899-ben, mert az ureterkatéteren nyert vizeletet szeparáltan lehetett vizsgálni. Korányi Sándor javaslatára a 


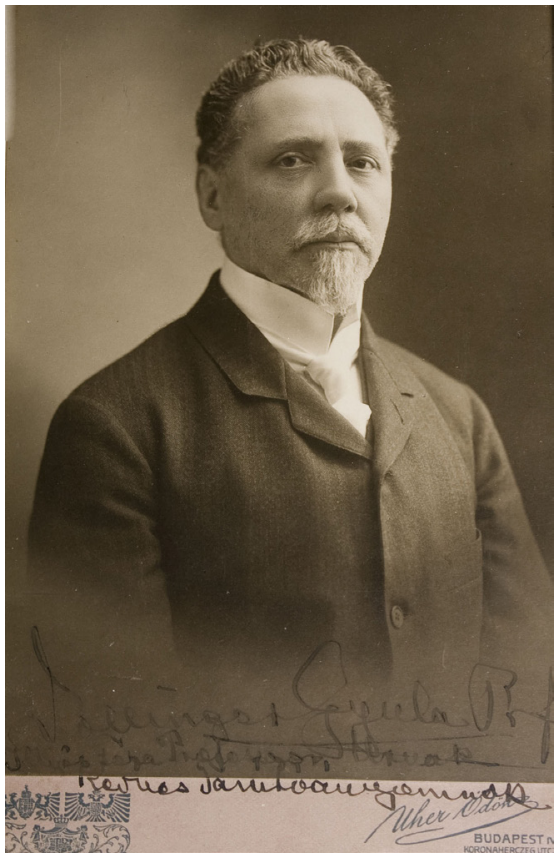

3. ábra

| Dollinger Gyula

vese funkciójára utaló fagyáspontcsökkenés vizsgálatát ültette át a gyakorlatba. (1974-ben, amikor a klinikára kerültem, a vizelet fagyáspontcsökkenését még vizsgáltuk.) Ez egy vese funkcionális vizsgálat volt, de az ureterről, a veseüregrendszerről morfológiai kép, ismeretek nem voltak.

Wilhelm Conrad Röntgen korszakos felfedezése után Illyésnek támadt az az ötlete, hogy ha egy 1,5 mm-es ezüstsodronyt helyez fel hólyagtükrön keresztül, és arról röntgenfelvételt készít, képet kap az ureter lefutásáról, helyzetéról. Ezt 1901-ben közölte az Annales des Maladies des Organes Génito-Urinaires szaklapban [4].

Ennél tovább is lépett: arra gondolt, hogy ha az ureterkatéteren keresztül röntgensugárfogó anyaggal tölti fel a veseüregrendszert és az uretert, pontos anatómiai képet kap. Bismuthum subnitricumot javasolt. Sajnos annak nyálkahártya-irritáló volta miatt az eljárás nem vált rutinszerúvé. A retrográd pielográfiát a Berlinben dolgozó Lichtenberg Sándor tökéletesítette, aki 2\%-os kollargolt használt, sikerrel.

1903 és 1905 között az I. Sebészeti Klinika urológiai ambulanciáját vezette Illyés. 1904-ben magántanárrá habilitálták. 1905-ben az Apponyi Poliklinika 32 ágyas urológiai osztályának vezetőjévé nevezték ki. 1937-ig 88 dolgozata jelent meg [5]. Első könyvét „Tapasztalatok a vesesebészet köréből” címmel 1913-ban adta ki. „Urológia” címü tankönyvét 1931-ben a Magyar Orvosi Könyvkiadó Társulat, 1932-ben az Universitas Könyvkiadó Társaság adta ki. Angol nyelvű könyve 1939-ben jelent meg. Az urotuberculosis a kiemelt témája volt.

1908-ban a Francia Urológus Társaság a tagjává választotta. 1910-ben levelező tagja lett a mai igen elegáns, kevés amerikai és még kevesebb európai taggal bíró

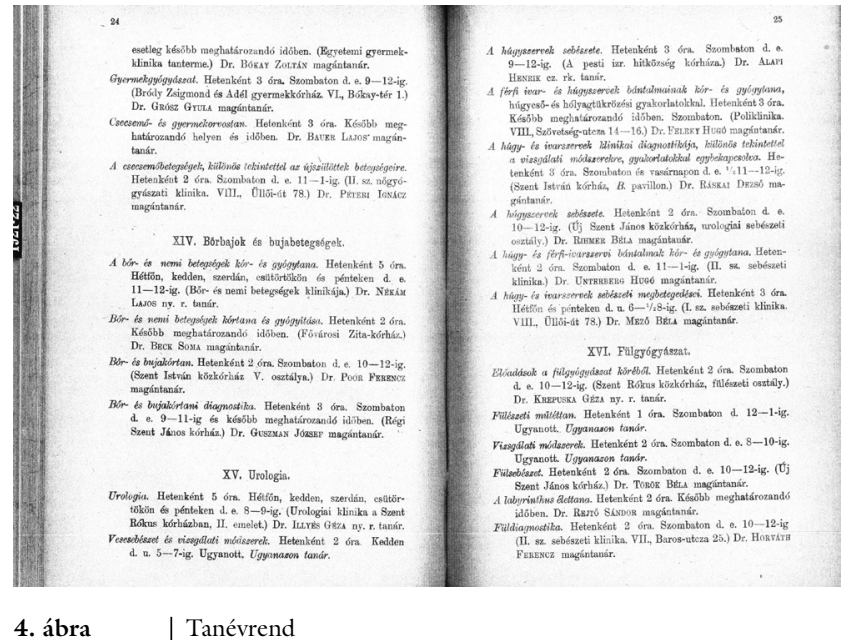

American Association of Genitourinary Surgeons-nek. (Európai változata, az Association of Academic European Urologists 2000-ben alakult, maximált taglétszáma 100 [!]. A szerző és utódja a két magyar tag.)

1913-ban a Szent Rókus Kórházban 102 ággyal urológiai osztályt nyitottak, főorvosnak Illyés Gézát nevezték ki. 1914-ben c. rk. (címzetes, rendkívüli) egyetemi kinevezést kapott [6]. 1915-ben bevonult katonának orvos alezredesi rangban. 1916-tól közel egy évet volt az olasz fronton. 1917-től ismét a Szent Rókus Kórházban dolgozott.

Az Egyetem szenátusa már 1916-ban - a háború közepén - foglalkozott azzal, hogy három tanszék szükségeltetne az új diszciplináknak: radiológia, orr-fül-gége és urológia. 1920. június 25-én a Szent Rókus Kórházban múködő urológiai osztályt klinikává, Illyés Gézát ny. r. (nyilvános, rendes) egyetemi tanárrá nevezték ki. 1920tól már szerepel is az urológia az egyetemi curriculumban (4. ábra). Illyés tekintélye itthon és Európában nőtt: 1925-ben a Zeitschrift für urologische Chirurgie szerkesztőbizottsági tagjává választották, 1930-ban az Argentin Urológus Társaság levelező taggá választotta.

Az 1922-től 1938-ig vezetett vendégkönyvben 106 amerikai és több mint száz, a világ más részeiről érkező látogatója volt a klinikának [7]. Volt amerikai, aki 1, és volt, aki 3 évet töltött a klinikán. Az utóbbi, dr. Lieberthal fordította Illyés könyvét angolra. 1936-ban Bécsben szervezték meg a Nemzetközi Urológus Társaság 7. kongresszusát. A vesegennyedések témakörének referálására Illyés Gézát kérték fel. Előadását 2616 feldolgozott eset alapján tartotta!

1936. szeptember 15-én az 1908-ban épült, volt III. Belklinikára, mai helyére költözött át az Urológiai Klinika. Ebben az évben lett Illyés a Magyar Tudományos Akadémia levelező tagja. Kitűnő operatőr volt, valóban iskolát teremtett. Munkatársaiból mind vezető urológusok, klinikaigazgatók (Minder Gyula, Babics Antal, Huth Tivadar, Balogh Ferenc) lettek.

70 éves korában nyugdíjba akart menni (1940), de a minisztérium meghosszabbította munkaszerződését 


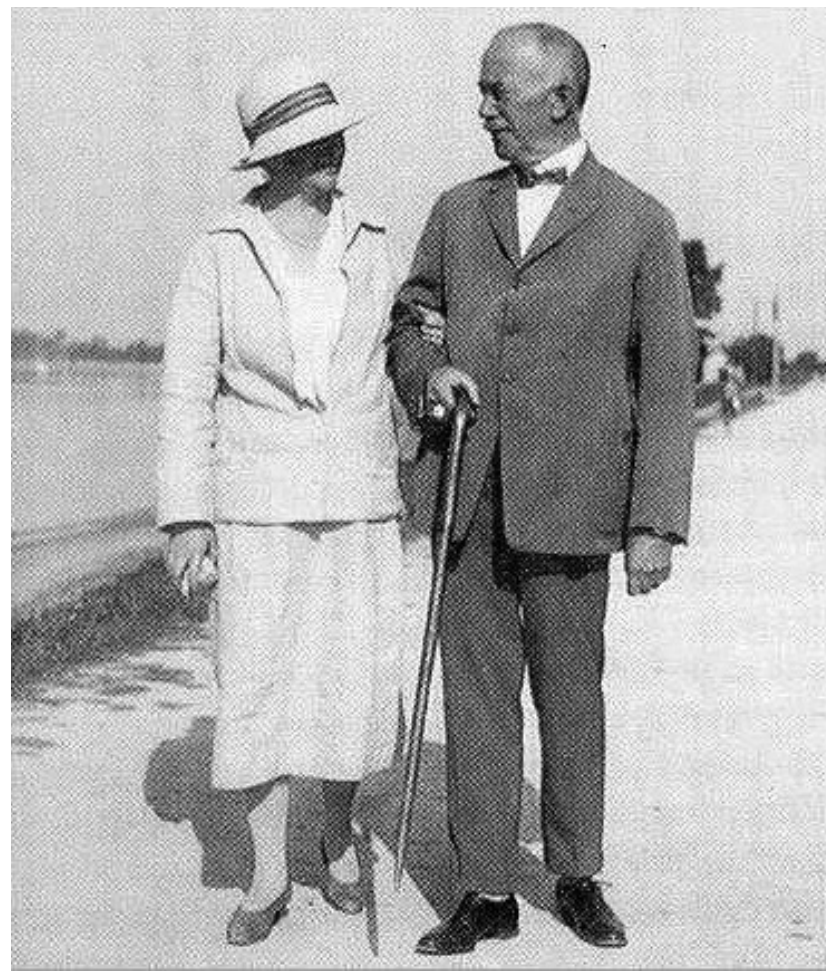

5. ábra

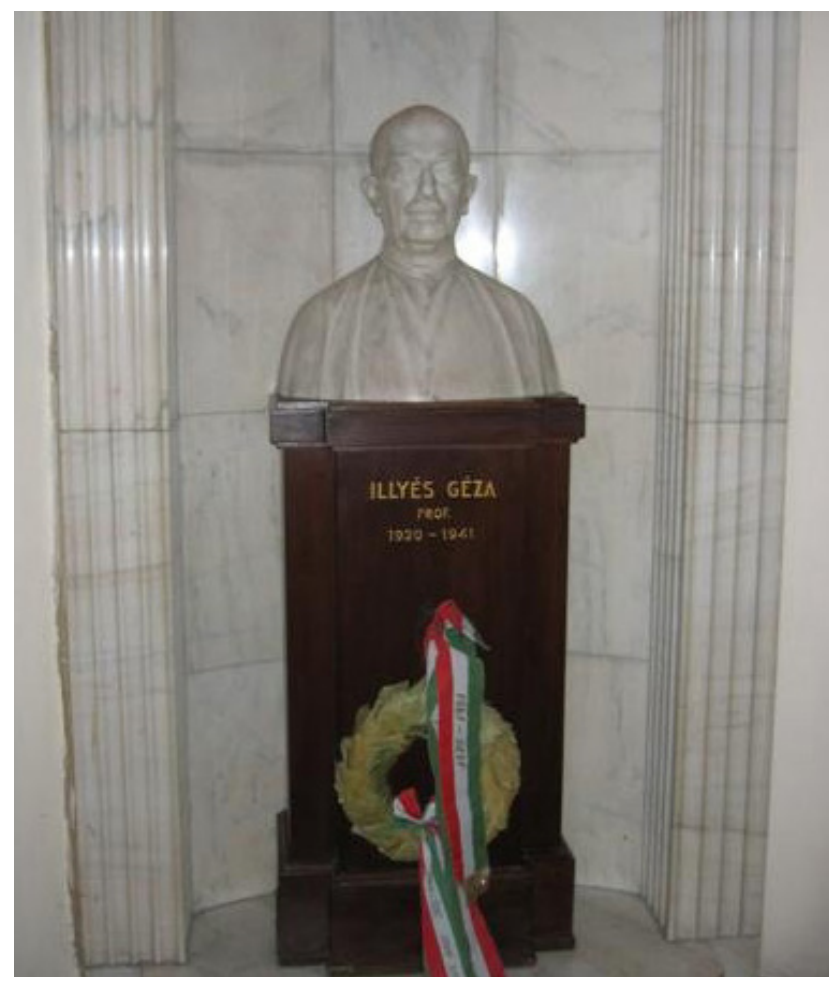

6. ábra

| Illyés Géza márványszobra
1941. augusztus 31-ig. Utoljára június 30-án volt bent a klinikán. Babicsnak, helyettesének a következőket mondta: „Nem akarok senkitől elbúcsúzni rajtad kívül, ne kísérjen ki senki a kapun. Ezt kérem Tőled. Vigyázz mindenre, amit rád bíztam."

1943-ban az Akadémia rendes tagja lett. Az ajánlók dr. Herzog Ferenc, dr. Manninger Rezső és dr. Orsós Ferenc voltak. 1949-ben az MTA Orvosi Osztálya elnökének nevezték ki.

Illyés a családjával, két lányával Budán, a Bartha utcában lakott. Minden nap 4 órakor egy órát sétált a Svábhegyen. Nagyon szeretett koncertre járni, otthon is sokat hallgatott zenét, egy Steinway zongora is volt a nappaliban.

Szerette a természetet, két autója volt, egy csukott és egy nyitott - az utóbbit gyakran ő vezette. A vakáció első 8-10 napját a Tátrában, a többi 5-6 hetet Balatonszemesen, üdülőjében töltötte. Itt napi egy órát lovagolt, sétált (5. ábra), naponta úszott, vitorlázott - írja Babics az Illyésról szóló könyvben [1].

Aktív nyugdíjasként hirtelen halt meg, 1951. augusztus 6-án.

Az Urológiai Klinika lépcsőházában áll egy Illyés-márványszobor (6. ábra); egy, a külföldi neves vendégeknek ajándékozható Illyés-Babics bronz emlékplakett emlékeztet rá, és az egyik mütőt is róla neveztük el.

\section{Irodalom}

[1] Babics A. Géza Illyés. [Illyés Géza.] Akadémiai Kiadó, Budapest, 1972. [Hungarian]

[2] Perjés G. Géza Illyés 1870-1951. In: Kapronczay K, Vizi ESz. (eds.) Famous Hungarian physicians. [Illyés Géza 1870-1951. In: Kapronczay K, Vízi ESz. (szerk.) Híres magyar orvosok.] Galenus, Budapest, 2000; pp. 19-23. [Hungarian]

[3] Balogh F. Professor Géza Illyés (1870-1951). [Illyés Géza professzor (1870-1951).] Orv Hetil. 2000; 141: 1088-1089. [Hungarian]

[4] Romics I, Fazakas Z, Nádas G. Géza Illyés, founder of Hungarian urology. In: Mattelaer JJ, Schultheiss D. (eds.) De Historia Urologiae Europaeae, Vol. 11. Historical Committee, European Association of Urology, Kortrijk, 2004; pp. 121-133.

[5] Romics I. Documents of the history of Hungarian urology. (Adatok a magyar urológia történetéhez.] Semmelweis Kiadó, Budapest, 2017. [Hungarian-English]

[6] Romics I. The 90-year-old urological department of Semmelweis University. [90 éves a Semmelweis Egyetem Urológiai Klinikája.] Semmelweis Kiadó, Budapest, 2010. [Hungarian]

[7] Romics I, Engel R, Stevens T, et al. The guestbook of the Urology Department of Semmelweis University in Budapest: a mirror of international contacts. J Urol. 2007; 178: 409-413.

(Romics Imre dr., Budapest, Üllői út $78 / \mathrm{B}, 1082$ e-mail: romics.imre@med.semmelweis-univ.hu)

A cikk a Creative Commons Attribution 4.0 International License (https://creativecommons.org/licenses/by/4.0/) feltételei szerint publikált Open Access közlemény, melynek szellemében a cikk bármilyen médiumban szabadon felhasználható, megosztható és újraközölhető, feltéve, hogy az eredeti szerző és a közlés helye, illetve a CC License linkje és az esetlegesen végrehajtott módosítások feltüntetésre kerülnek. (SID_1) 